\title{
研究報告
}

\section{小児看護実践で看護婦が直面する 倫理的問題と看護婦の対応}

\author{
井上 みゆき*
}

\section{Ethical Problems in Pediatric Nursing : Nurses' Experiences and Attitudes Toward These Problems}

\author{
Miyuki Inoue \\ Graduate School, Nursing Nagano College of Nursing
}

キーワード : 小児看護実践, 倫理問題, 看護婦・士

Key words : pediatric nursing practice, ethical problem, nurse

\begin{abstract}
This study examined ethical problems in pediatric nursing and the nurses' attitudes towards these problems. The methodology was qualitative. Unstructured, tape-recorded interview data were collected from 18 pediatric hospital nurses with more than five years of clinical experiences. The nurses confronted ethical problems on a daily basis and these were categorized into the following topics : 1) life-prolonging treatment, 2) informed consent, 3) child human rights, 4) education of staff nurses, 5) care environment. Although the nurses identified these problems as ethical issues, they took no action because they defined their role as having severe limitations.

Directions for solving these problems emerged from the data : 1) nurses' need to further develop ethical sensitivity, 2) more advanced clinical and academic nurses who can assist nurses to develop greater ethical sensitivity, and 3) nurses' empowerment that can change the health care environment so that the nurse fully takes the patient advocacy role.
\end{abstract}

\section{要旨}

本研究は，小児看護実践で看護婦が直面する倫理的問題とその問題を解決する看護婦の 対応を明らかにすることを目的とした，対象は，小児専門病院へ勤務する小児看護経験 5 年 以上の看護婦 18 名である。デー夕収集は非構成面接を行い, 得られたデータから質的帰納 的分析を行った. 小児看護実践で看護婦が直面している倫理的問題は，1)延命治療の是非, 2) 医療の情報提供の不足，3) 子どもの人権が尊重されていない，4)看護婦の継続教育の不

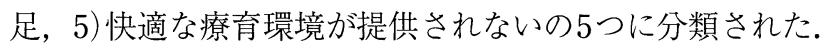

*長野県看護大学大学院看護学研究科 
看護婦は，倫理的問題を感じてはいるが，看護婦自身の問題と捉えていないために倫理的問 題を解決する行動はとっていなかった．これらの問題を解決するためには，1）日々の看護実 践を通じて自らの倫理的感受性を発達させる．2)看護婦が倫理的感受性を高めて行くこと を助ける人的資源 (CNSなど). 3) 看護婦が患者の擁護者としての役目を果たせるよう, 看 護婦のパワーで職場を変化させて行く必要性が示唆された.

\section{I . はじめに}

医療技術の進歩に伴い, 人間の尊厳を守ると いう観点から倫理の問題がクローズアップされ てきている，看護は人間を対象としており，あ らゆることが人権に関連している可能性がある (井部, 1998). 看護倫理の意思決定において最 初に必要となることは，その状況が倫理的な問 題を呈しているかを見きわめることであるとし ている(Davis \&太田, 1999)。 また, Davis (1998)は, 臨床実践の中の構造と倫理的問題を 解決するのは，その国の文化に適合する倫理基 盤を決定することであると述べている.

日本における看護倫理と生命倫理に関する多 くの考え方は, 西洋の哲学的伝統に基づく倫理 (Beauchamp \& Childress, 1994) に由来してい る. 従って, 伝統的な神道や儒教, さらには仏 教の影響を受けた倫理観が深く根付いている日 本の文化・習慣・価值観などを考慮した場合, 西洋のEthicsをそのまま用いることは困難では ないかと考える。しかし，日本特有の倫理原則 やケア倫理は確立されていないのが現状である. 日本での小临看護実践における倫理の文献は非 常に少なく, 横尾 $(1996,1997)$ は, 倫理的意思 決定の問題と看護婦の価值観や親の意思決定へ の参加について明らかにしている. 小笠. 横尾 （1999）は，新生児看護に内在する倫理的問題を 取り上げ新生児看護の課題を考察している。ま た，筒井 (1994) は，倫理の定義・原則などを通 して小児看護と倫理について述べている，小児 看護の場合は, 対象者が言語能力や理解力が未 熟であるので，意識的に看護婦が倫理的問題を 表出していくことが重要となる.

研究者の 18 年間の臨床経験から小児看護実践 での倫理の問題は, 生命の選択, 延命だけでな く, 日々の看護実践の中でも多くの問題が生じ
てきていると思われる。そこで，小児看護実践 で看護婦が直面している倫理的問題とその問題 を解決するための看護婦の対応を明らかにする 必要があると考えた。

\section{II. 目的}

本研究は，小児看護実践で看護婦が直面する 倫理的問題とその問題を解決する看護婦の対応 を明らかにすることにより，小児看護実践に生 じる倫理的問題を解き明かす一助とすることで ある。

\section{III. 研 究方法}

\section{1. プレテスト}

小児専門病院に勤務しており, 小児看護経験 が 5 年以上ある看護婦 3 名を無作為に選択してプ レテストを行った。しかし倫理的問題とは何か がわからず答えられなかった。

従って, 研究者が小児専門病院で共に働き倫 理的問題に関心があると感じた看護婦を始めに 対象者とし，その後倫理的問題に関心がありそ うな看護婦を Snowball Sampling (Polit \& Hungler, 1995)にて選択した.

\section{2. 研究対象者}

小児専門病院に勤務し小児看護経験が 5 年以 上あり，倫理的問題に関心があると思われた看 護婦である。

\section{3. データ収集方法}

1) デー夕収集: 非構成面接

2 ）期間: 平成 10 年 8 月 14 日 平成 11 年 3 月 31 日まで 


\section{4. データ収集の手順}

1 ）研究協力を文章にて依頼した. 研究協力を 得られてから面接まで1日以上あけ倫理的問 題について考える時間とした.

2) 面接は公的，私的にも忙しい時は避けた.

3 ）面接は個室で行い, 所要時間は決めず対象 者の自由とした。

4 ）面接の内容は，日常の小児看護実践で感じ る倫理的問題と倫理的問題を解決するための 看護婦の対応を自由に語ってもらった。

5 ) 面接の内容は許可を得て録音した。

\section{5. データ分析方法}

1）語られたデー夕は逐語記録に起こした.

2 ）語られたデータの大まかな意味を得るため に，記述されたデータを通して読んだ。

3 ）記述されたデータから国際看護協会の『看 護の規律，看護に適用される倫理的概念』 1973年 (Fry, 1994/1998, p.125-199)を参考に 倫理的な問題と思われる内容を文章ごと抽出 した.

4）抽出された文章を内容が同じものに分け, 共通する意味を見出した.

5 ) 得られた結果を対象者に読んでもらい, 結 果の確認, 修正を行うことで信頼性, 妥当性 を得た。

分析は質的研究の経験者, 小児看護経験 20 年 の実践者，小児看護経験 18 年の研究者で行っ た.

\section{N. 結 果}

\section{1. 対象の概要}

対象者：看護婦 18 名. 看護婦経験歴：成人看 護の経験者 4 名, 精神看護の経験者 1 名, 小児看 護の経験のみ 13 名. 年齢平均 : 34.5 歳 $(27$ 歳 41 歳)。看護経験平均： 11 年 9 ケ月 ( 5 年 5 ケ月 19 年 11 ケ月). 小巟看護経験平均：9年 8 ケ月 ( 5 年 5 ヶ月 $\sim 16$ 年 6 ケ月). 専門職歴: 短期大学 2 名, 専門学校 ( 3 年課程) 13 名, 専門学校 $(2$ 年 課程) 3 名.

看護婦の病院内での所属は, 新生览病棟, 小 児内科系病棟, 小児外科系病棟, 外来, でほほ
均等に各領域から選択された。

\section{2. 面接時間}

平均100分 (70分から120分)

\section{3. 倫理的問題に対する看護婦の反応}

倫理的問題に関心がある看護婦を対象者とし て選択したが，研究依頼を看護婦に行った時の 反応は，“倫理的な問題”とはどのような問題な のか? という質問を多く受けた。研究者は面接 への影響を考え，「倫理的な問題と言われ，自分 で感じる問題を答えてほしい」と話した。また, 面接を開始してからも看護婦は，「これが倫理的 な問題として正しいか」と質問してきた。しか し，看護婦が倫理的問題かどうか不安を示しな がらも語ってくれたことは，すべて，倫理的問 題であった。そして，看護婦は，そのことが倫 理的問題であるとわかるといつ, 誰が，どこで, どうしたのか，とストーリーとして語った。

\section{4. 小児看護実践で看護婦が直面している倫理 的問題}

記述されたデータから分析された看護婦が日 常の小児看護実践で直面している倫理的問題は, 延命治療の是非, 医療の情報提供の不足, 子ど もの人権が尊重されていない, 看護婦の継続教 育の不足，快適な療育環境が提供できない， 5 つに分類された。 以下，小児看護実践で看護婦 が感じている倫理的問題について, 報告例を挙 げながら分類された意味別に示す。

\section{1 ）延命治療の是非}

看護婦は，子どもの最善を考え，親の価值観 を尊重し推進したいと思っても，延命治療の是 非が医師一人で決定されることや，治療成績を 上げるために延命治療がなされている状況を倫 理的問題としていた.

「危険な状態で手術をしたり，治療して結局产れ が点滴を毎日して挿管されて呼吸器につながれ てということになると, 何かあっちこっち切ら れて，お母さんもあまり抱つこできなくて終わ っていくことが，子どもにとって良いことなの かな一と…..」

「お母さん看護婦だったので，点滴持ってお家に 
連れて帰りたいって希望したのに，主治医が救 急車で帰っても，救急車の中で死可能性があ るからダメだって言うんです。㫕れでも, 親は 帰りたいって言うんです」

「OP後の日数を稼ぐためにもうだめだってわかっ ていても治療成績を上げるために一日でも長く 生きるようにしていた，ものすごい圧でバギン グして気胸になると脱気していた，何のために やっているのかって感じていた. 子どものこと や親のことなんか考えていない，自分達(医師) の利益になることしかって感じ. OP後の失敗 にならないために治療を積極的にしている．何 でもかんでも積極的にする治療に疑問が残る」

看護婦は, 痛みを伴った処置をされ，親に抱 かれることもできず，人工呼吸器につながれ， ただ命を長くすることが子どもや家族に害を与 えているのではないかと感じていた。 そして延 命治療の決定は医師のみで行われていることに 問題を感じていた。多くの看護婦はこのような 状況の倫理的問題について語った.

\section{2 ）医療の情報提供の不足}

医師からの病状や治療の説明が不足している ため, 子どもや親が病状や治療を正確に判断で きない状況にある。

「親は，素人だから囟にもすがる気持ちがある.. …先生も期待を持たせることを話すし, 予後と かはっきり話していないと思う. 例えば, 私に 4人目の子どもが出来て頭もやられて，気管切 開しなければ家に帰れないって言われたら，何 もしないでくれって言うと思う. 3人子どもい るし, 今の生活やっていけないから. でも第1 子で仕事していなかったら何でもやってほしい と思う」

「白血病とかでもう回復の見込みがなくて，医療 者側としてもう亡くなるだろうっていう子がい た場合，どの時期にお母さん達にある程度の見 通しを……何ていうか……自分だったら突然言 われたらびっくりしちゃうから，ある程度予測 ついた段階で先生から話した方がいいと思う。 家族も心構えができるから，看護婦からは关う いった話はできないから. 以前，入院した子の お母さんから看護婦さんは，この子が亡くなる
ことはいつからわかっていたか?質問されたこ とがあった」

医師は，生命を最も優先し治療を行っている， 治療についての説明は両親へ行っているがその 治療に効果, 予後, 副作用, などの今後の予測 を説明していない，例えば，気管切開をして人 工呼吸器をつけて在宅ケアとなることでの親へ の負担，子どもへのリスクなどの説明がない. 看護婦は, 経験的にその子どもの予後の予測が つくと考えている. しかし両親は, 未経験のこ とであり，予測がつかずに正しく治療への意思 決定ができないことに問題を感じていた。

\section{3 ) 看護婦の継続教育の不足}

看護基礎教育が大学へと変化し, 大卒の新人 看護婦が増加している一方, 臨床看護婦の継続 教育に変化がないままの状態で新人教育を行っ ている。また, 臨床に倫理的問題についての教 育の場がない。

「看護教育の変遷が大きくあるから，自分自身の 時と比べるとかなり違う. (略)自分は違う過程 (専門学校)を経てきているので不安がある.入 ってきた時点での教育のされ方が全然違うのに 現場の教育が変わっていないので果たしていい のか，これでは現場での看護の発展がない」

「病院に看護倫理の教育がないというのが大きな 問題だと思いました. 認識していても組織的に 検討していく場がないのが問題. あるのかも知 れないけど上だけでやっていて末梢まで伝わっ てこない」

看護婦は, 看護基礎教育が大きく変わり, 今 までと違った価值観，看護観を持った看護職が 就職する中で, 新人を指導する看護職の継続教 育に変化がないまま新人指導を行うことは, 看 護の発展の妨げとなるのではないかと感じてい た。また，臨床現場で看護倫理の教育がなされ ていないので，看護婦の中に倫理観が育たない としていた。臨床看護婦の継続教育が十分行わ れていないため, 看護婦は, 専門的知識の発展 を積極的に行うことができないことを問題にし ていた。 
4 ）子どもの人権が尊重されていない

子どもの名前を呼び捨てにする，子どもに無 断で写真を撮影する.

「子どもの名前が呼び捨てだったりとか，おまえ とか，みんな一生懸命ケアしているのはわかる けど‥ここに親がいたら聞かせられないなって 思うことがある. 大人ではそういう事はないで すよ. 大人対大人だから」

「看護婦が親の承諾を受けないでお好みで写真撮 影がなされる.かわいいとかの理由だけでなさ れている. プライバシーとかの問題があるから 親の承諾の基に取らせていただくのはいいけど」 この状況は，成人看護経験者から小児看護を 経験してはじめに感じたことであると語られた。 小児看護特有の問題でもある。看護婦と子ども との間に上下関係が生じている。しかし，小児 看護だけを行っている看護婦は，このことを問 題として意識していなかった.

\section{5 ）快適な療育環境が提供できない}

看護婦不足や病棟の状況で，夜間，子どもを 薬で眠らせる，子どもの要求に答えられないな ど，子どもに快適な療養環境が提供できない状 況.

「一番長い間，看護婦と接しているわけで，長期 の子はもう何年もいるわけで, 看護婦から与え る影響は大きいわけで，もっと接してあげたり とか，関わってあげることで発達に良い影響を 与えることができるんじかないかって思う. で も本読んでって言われても処置に追われてなか なか読めない」

「お母さんが付き添ってない子はどうしても泣く じかないですか，夜勤は看護婦の人数が少ない から，どうしても寝かせるために薬を使って寝 かせるんです、トントンしてやったり，抱っこ したりしたら落ち着くと思うんです」

看護婦は子どもに最善のケアをしたいと考え ながらも，病棟の状況でそれができないことに 強いジレンマを感じていた。

\section{5. 倫理的問題を解決するための看護婦の対応}

倫理的問題を解決するための看護婦の対応は, 医療者同士の話し合い，医療者と患者の親との
話し合い，病院としての対応を決めておく，看 護婦を増員してもらう，親と医師の間にたちメ ッセージを伝えるの5つに分類された。

看護婦は，小児看護実践で感じている倫理的 問題を語ったときとは違い一文で語り終えた。

以下，報告例を挙げながら分類された意味別 に示す。

1) 医療者同士との話し合い

「医師と看護婦とでもっと倫理的なことにつ いて話すべきだと思う」「看護管理者がもっと強 くなって，医師との話し合いの場を設けてどん どん意見を言えるようにならないとだめだと思 う」

2 ）医療者と患者の親と話し合い

「出来たら，私は親の意見を聞いていきたい けど，医師の考え方一つでその子の一番良いこ とが決められていくから，医師が考え方を変え ないと難しい」「親と先生と看護婦がじっくり話 し合える時間を作ること」

\section{3 ）病院としての対応を決めておく}

「延命治療の問題は，ある程度，病院の方針 が必要だと思うから，管理者に考えてほしい」 「病院が倫理問題を解決する場を持つこと」

\section{4) 看護婦を増員してもらう}

「私たちが解決するのは難しい，まずは，看 護婦の人数が増えないと」「同じ患者さんを継続 して見ていく，本当のプライマリーナーシング が理想，でも，プライマリーをやるのは看護婦 が増えないと難しい」

\section{5 ) 親と医師の間にたちメッセージを伝える}

「まずは，親の気持ちを聞いて，親と良く話 して，親の気持ちをまず先生に伝える」「看護婦 が親の気持ちを伝えても，それを受け止めてく れる医師がどれだけいるかって感じ……特に長 がつく偉い人」

看護婦が倫理的問題を解決するための対応は, 理想とするものであり，実際行動はとっていな かった。また，今の医療現場では，倫理的問題 
解決の行動は，医師，病院，管理者でなければ とれないとした。

\section{V. 考察}

\section{1. 倫理的問題に対する看護婦の反応}

福留 (1999)は, 看護実践が行われている現象 の中から倫理的問題を敏感に感じ取り，「倫理的 感受性」を洗練され，倫理的問題を含む現象に 適切に対応することが看護職の責務の一要素に なるとしている，看護職は，まず看護実践の場 で倫理的問題が生じているかどうか認知するこ とができなければならない。

しかし本研究のプレテストでは, 倫理的問題 が何かわからず答えられなかった看護婦もいた。 また，倫理的問題に関心があると思われた看護 婦でも，自分が語っている問題が倫理的問題な のか不安を示した。そして看護婦はこの研究の 面接で初めて，この出来事が倫理的問題である とあらためて認識していた。このことは，日常 の看護実践の中で看護婦は，意識的に倫理問題 を捉えていないことが多いと思われる。岡谷 (1999)の調査でも, 看護職は日常の看護業務で 体験するさまざまな問題を看護倫理上の問題と して捉える視点が弱いと言えるのではないかと 述べている．南(1999)は，約15年の臨床経験の 中で倫理的問題に焦点を当てて考えられるよう になったのは最近のことであり，そのきっかけ となったのは, 職場や看護協会の倫理委員会の メンバーになったことで，これらの委員会から 倫理的感受性の育成に必要なサポートを受けた ことであるとしている，尊い人間の命に関わる 仕事である看護婦として，倫理的問題を見きわ める能力は非常に重要なことである，倫理的感 受性を発展させるためには臨床的倫理教育方法 として，教室を用いた正規の講義よりも臨床の 場を用いた非公式の指導によって特徵づけられ るとしている.これらは, 臨床カンファレンス, 事例報告，倫理回診である（Fry, 1994/1998, p.208).

中島 (1993)によれば米国では倫理的葛藤のあ る場面において小児癌専門看護婦は, スタッフ ナースからの情報をまとめ, 自らの倫理的役割
を「患児とその家族の代弁者, 支援者」とみな していることが明らかにされている，日本にお いても専門看護師の教育課程認定の際には, 倫 理的な暮藤が生じた場合に関係者間での倫理的 調整を行える能力を持つことを表明している (日本看護系大学協議会平成 5 年度専門分化検討 委員会, 1995). 小览の専門看護師の誕生は, 臨 床の場で倫理的問題解決の一旦を担うことが期 待できると思われる。

現状の臨床の中で看護婦が倫理的にどうなの かという観点で日頃の業務に向かうためには, 個人の努力のみに期待することは難しく, 何ら かのサポートをしてくれる人的・物理的資源が 必要であると思われる。

\section{2. 小児看護実践で看護婦が直面している倫理 的問題}

延命治療の是非は, 医療において何が最善で あるか, 子ども, 親, 医師, 看護婦など個々の 価值観によって異なる。医師が行った決定が, 両親の意思決定と異なってしまうこともある. 成人ならば個人の意思が優先されるのだろうが, 自分で意思決定を扔こなえない子どもの場合は, 誰の意思決定が優先されるのか. 日本では，倫 理原則や倫理的意思決定の枠組みがなく，その 場，その場で対応しているのが現実ではないだ ろうか. 小児の延命治療に関する決定において は，いろいろな人たちの意向が重要となる.中 でも，子どもの両親の意向が最も重要である (Jonsen, Siegler \& Winslade, 1992/1997, p.175). 看護婦の役割は, 両親の意向の適切さと重要性 を評価し，矛盾がある場合にはこれにどう対処 するかを決めることであると考える。そして看 護婦は，子どもや親にどれだけ誠実に行動でき るかが問われているのではないだろうか.

また，延命治療の是非と医療の情報提供は， 複雑に絡み合っており医療の情報提供が正しく 行われていないために, 親が治療の決定を行え ず延命だけの治療を行う結果になることもある. 気管切開などの処置を行う時に命を助けること を最優先する医師と，その子どもと家族も視野 にいれてケアしょうとする看護婦の間にズレが 生じていると思われる。すなわち，“医師は病気 
を診ている”に対して“看護婦は親子を看てい る”ズレが問題となっている.

看護は, 従来から「患者中心」に行為するこ とに専念してきた。しかし，「何が患者のため」 なのか「何をなすべきなのか」を判断する基準 を生物学的治療中心の医学に頼ってきた。つま り，看護職は，たとえケアの概念とされる「相 手の必要に応じる用意」を十分にもち合わせ, 患者のニーズを汲み取れる共感的受容的な構え を持っているとしても，「必要性とその理由」に おいて十分な判断を下す能力を身につけていな いと考える。看護は，利益の擁護という根拠を 必要とする(石本, 2000).「擁護」という用語は, 看護婦と患者の関係の性質を述べる時にも用い られる。保健医療において看護婦は，患者の権 利の擁護者となる場合が多い。看護婦には患者 の権利について患者自身に情報を与え，それら 権利について患者が理解したことを確認し，患 者の権利侵害について報告を行い，かつその権 利侵害の進行を防止することが求められる (Fry, 1998).

看護婦は，患者へ情報を提供して患者に選択 の幅をもたせ，患者の意思決定を支えていくこ とが専門職としての責務の1つであろう。

しかし看護婦はこの状況を改善したいと思っ ても，臨床現場には医師に従わなければならな い医師一看護婦関係が存在しており, 看護婦か らその状況を変化させることが出来ないでいる。 Fry \& 小島(1998)も，日本の看護婦が「困って いる倫理問題」として挙げているものすべてが 医師との関係，あるいは医師が関係している問 題であることを明らかにしている。そしてこの ことは，日本の特徴としている，日本文化の中 には，意識していなくても儒教は非常に大きな 影響を及ほしており，お互いの調和を重視し， 個人というよりも全体の中での調和が非常に重 視されている。また，日本の組織は，リーダー と同じ価值をもつことが求められる，もしリー ダーが変わるとそのリーダーに合わせて価值も 変わることになる (手島, 1998).このような日本 の文化背景は，患者自身も医師に従うことがよ いこと考えられ，看護婦が患者の擁護者になる ことを難しくしている一因とも考えられる。片
田(1999)は，患者のアドボケートになる方法論 の部分で開発が遅れていた現状は否めないとし ている．今後，日本の文化も視野に入れた看護 婦が患者の擁護者になる方法論の開発が必要た と考える.

子どもの人権の倫理的問題は, 看護婦が行っ た行為に対して看護婦が倫理的問題と感じてい ることである. しかし, 倫理的問題と感じた看 護婦自身もその問題を表出することができない でいる.看護婦の倫理についての知識の欠如が このような状況を生む背景となっていると思わ れる。また，看護婦の意識の中に，看護婦一患 者関係が上下の関係になっていると考えられる. 意志表示や言語能力の未熟な子どもたちを対象 とするので, 看護婦自身が子どもの人権や尊厳 を守るという意識を持たなければ対象者の人権 が守れないことを認識すべきである.看護職は 自分たちで判断していることを自覚する訓練, そして行動に移す訓練を重ねることが重要であ ると考える(片田, 1998).

看護婦は, 看護系大学卒業の看護婦が増える 一方，臨床の中で継続教育がないまま看護婦の 新人を教育することは，看護の質の向上につな がらないとしていた。

看護基礎教育は 1990 年に入り大きな変化がも たらされた。1991年には11校であった看護系大 学は1999年4月には76校になり今後も増加傾向 にある(日本看護協会編, 1999)。看護基礎教育 を大学で受けた看護婦が増加する中で, 臨床の 現場で新人の教育を行っている看護婦のほとん どは，専門学校卒または短期大学卒である。新 人を教育する看護婦は自分が受けたとこのない 教育背景の看護婦への指導に戸惑いは大きいと 思われる，看護教育へ倫理教育が取り入れられ たのは，最近のことである(小島, 1998 ; 荻野, 1996）。日本看護協会が国際看護協会の「倫理 規定」を基に「看護職の倫理規定」を制定した のは，1988年である(林, 1994, p.139)。言い換 えれば今から 12 年前までは，日本には，看護職 の倫理規定がなかったことになる．小島(1998) によれば，看護倫理の教育が系統的に行われな かった教育の影響の一つとして, 自分の倫理観 を育てないまま臨床現場に出ている先輩看護婦 
から学ぶことは困難で, 実地に看護倫理を学習 できるはずの貴重な機会を逃しているとしてい る。急増する倫理的問題に対して, 看護婦とし て倫理観を持ってこれらに立ち向かい，倫理的 判断を行うには系統的, 継続的な倫理教育が必 要であることは確かである.

しかし，臨床での継続教育も倫理教育も，病 院や管理者が教育の場を整えるだけでなく，継 続教育の必要性を感じたら自ら学ぼうする姿 勢が重要ではないだろうか. 国際看護婦協会の 「看護婦の規律」(Fry, 1994/1998, p.x)は，“看護 婦は継続的学習により看護実践と能力を維持す ることに対し，個人としての責任を有する”と いう看護実践の倫理基準を含んでいる．継続教 育の問題を語ってくれた看護婦は，自分自身の 問題として継続教育を捉えていなかった。個人 の責任として捉え，自ら学んでいくことを必要 としている.

子どもの人権を守ることも, 臨床看護婦の教 育も，実例を見ると医療者の倫理的姿勢，その 人の行動原則における倫理性の問題が多く取り 上げられている。

快適な療育環境は，子どもにとって最高のケ アを提供したいと思う看護婦と職場の人的・物 理的環境の問題である。看護婦は，薬で眠らせ ることや子どもの要求に答えられないことが子 どもの発達に良くないことであると認識しなが らも，マンパワー不足により質の高いケアの提 供ができないことにジレンマを感じている。こ のような状況は，看護婦のケアへの意欲を喪失 することにより，子どもが不利益を被り看護婦 も無気力や不満を募らせ，意欲減退や燃え尽き 症候群を生み出す背景となる可能性を含んでい ると見ることもできる(志自岐, 1996). 看護婦が 子どもに対して責任をもって判断し行動するこ とができる職場環境が大切である。職場の人 的・物理的環境を変えていくには，本当に変え るためには何が必要なのかを自分に問うことで ある。やりたいことがあるところにエンパワー メントは起こるのである(南, 1997).

小児看護実践に倫理的判断を統合することは， 小児看護実践の必要性や正当性を確認すること につながり，質の高い看護が提供できると考え
られる。

\section{3. 倫理的問題を解決するための看護婦の対応}

看護婦は倫理的問題を感じていたが倫理的問 題を解決するための行動はとっていなかった. 子どもを擁護できる医療に変えていくには，異 なる価值観を受け入れ，意志決定をしていく医 療全体のシステムが不可欠である。そして, 看 護婦はそのようなシステムの中で自らの考えを 表明し, 役割を果たしていかなければならない. しかし，看護実践での看護婦の行動は組織の中 での力関係に負うところが大きい. 従って, 個 人の努力のみに期待することは難しい.

病院組織は看護婦が倫理的問題と捉えた事柄 を訴える場を持ち, 組織的に検討され, 検討さ れた結果を実践へ返すという循環メカニズムが 必要であると考える。しかし, 深津(1997)らに よれば，日本で倫理委員会を設置している病院 は, 病床数 300 床以上の大規模な病院であって も $24.4 \%$ であり，病床数 100 299床では $5.7 \%$ である。また倫理委員会が設置してある病院で あっても開催に必要な委員の召集・運営が困難 であるとされている。このような日本の現状の 中で看護婦に何ができるのか. まず，日常の小 览看護実践の中で直面する倫理的問題の事例を 取り上げ，その状況が起こったのはなぜか，そ の問題にどのような倫理的問題が存在するのか, そこに関わる価值が存在するのか, 誰の価值か, 自分はどのような価值を持っているか, 看護婦 としてのどのような責任を果たすのかなどにつ いて看護婦同士での話し合いの場を持つことが 必要であろう。続いてその話し合いの場が病棟, 病院へと徐々に拡大していったらよいのではな いだろうか。病院組織の中で看護婦数は圧倒的 に多い。看護婦のパワーで病院組織を变革でき るように看護婦自身が倫理的感受性を磨くこと が重要であると思われる.

\section{V. 研究の限界と今後の課題}

国際看護協会の「看護の規律」は，看護実践 の基準の中心となるものである。そして世界各 国の看護婦の倫理規定を作成する基礎となって 
いる。しかし，西洋の倫理原則を基にしている ため，日本文化から倫理問題を捉えた場合，ぴ ったりいかない部分もある。今後は，日本の文 化を背景にした看護婦の倫理規定の開発が必要 と考える.

また，小児看護経験 5 年以上としたことによ り，4年以下の小児看護実践者を対象としてい ないので，今回の結果を一般化するには限界が ある。

\section{謝 辞}

稿を終わるにあたり，ご協力くださいました 安藤まり子婦長，貴重な時間を割いて面接に応 じてくださいました看護婦の皆様に心より感謝 申し上げます。

(本研究の一部は第19回日本看護科学学会学術 集会において発表した。）

\section{引用文献}

Beauchamp, T.L. \& Childress, J.F. (1994): Principle of Biomedical Ethics (4th edition), Oxford University Press, Oxford.

Davis, A.J., 太田勝正 (1999)：看護とは何か一看 護の原点と看護倫理一，116，照林社，東 京.

Davis, A.J. (1998)：看護の統合機能と倫理 日 本人看護倫理の一層の啓発を統合されるも のは何か, 日本看護科学学会誌, 18(2), 28.

Fry, S.T. (1994) /片田範子，山本あい子(1998)： 看護実践の倫理 倫理的意思決定のための ガイド，日本看護協会出版会，東京.

Fry, S.T., 小島操子 (1998)：看護実践における倫 理と人権問題に関する調査：米国と日本, 21 (5), 57-62.

Fry, S.T.(1998)：倫理教育への看護実践への応 用，インターナショナル・ナーシング・レ ビュー, 21 (5), 35-41.

深津宣子, 赤林朗, 甲斐一郎 (1997)：日本の一 般病院における倫理委員会の設置状況およ び倫理的問題への対応の現状，生命倫理, 7 (1), 130-136.

福留はるみ (1999)：倫理的感受性と倫理的意思 決定 倫理的問題を明確にするためのロン
プソンの分類について，看護, $\mathbf{5 1}(2), 32-38$. 林 滋子編 (1994)：看護実践と概念 第 2 版, 139-142, 日本看護協会出版会.

井部俊子 (1998)：問われる看護者としての倫理 的責任一日常直面するケアの場面から，看 護, 3月特別臨時増刊号, 4-26.

石本傳江 (2000)：患者の利益擁護者としての看

護, Quality Nursing, 6 (4), 67-71.

Jonsen, A. R., Siegler, M. \& Winslade, W. J. （1992）／赤林朗, 大井玄, 大井幸子 (1997)：臨床倫理学 臨床医学における倫 理的決定のための実践的なアプローチ, 新 興医学出版社, 東京.

片田範子 (1998)：看護実践における倫理的課題 兵庫県立看護大学第 4 回国際セミナ一, 看 護管理, 8 (2), 128-133.

片田範子 (1999)：看護の立場から，生命倫理, 9 (1), 194-196.

小島操子 (1998)：看護倫理：看護教員としてこ

う考える，Quality Nursing, 4(1), 4-8.

南由起子 (1999)：倫理的感受性の育成に必要な サポート，看護, 51 (2), 62-66.

南 裕子 (1997)：日本に打ける看護のエンパワ

ーメント，看護管理, 7(1), 28-32.

中島光恵 (1993)：倫理的葛藤のある場面でにお

ける小児癌専門看護婦の役割と看護実践に 影響を与える因子 3 人の米国小览癌専門 看護婦の面接より, 千葉大学看護学部紀要, $15,139-143$.

日本看護系大学協議会平成 5 年度専門分化検討 委員会 (1995)：専門看護師 (士)養成のため の修士課程におけるカリキュラム，看護教 育, 36 (3), 257-259.

日本看護協会編 $(1999)$ ：平成11年度版看護白書,

日本看護協会, 136 .

小笠幸子，横尾京子 (1999)：新生児看護の現在 と臨床倫理, Quality Nursing, 5(11), 40-45. 荻野 雅 (1996)：看護倫理をどのように教える か? 看護倫理教育への示唆, $37(1), 17-20$, 看護教育.

岡谷恵子(1999)：看護護業務上の倫理的問題に 対する看護職者の認識 日本看護協会〈日 常業務上ぶつかる悩み〉調查より，看護， 
51 (2), 26-31.

Polit, D. F., Hungler, B. P. (1995) : Nursing Research Principles and Methods(Fifth Edition), J.

B. Lippincott Company, Philadelphia.

志自岐康子 (1996)：臨床看護における看護婦の

行動と責任一倫理的問題状況に焦点を当て

て, Nursing Today, 11 (10), 10-13.

手島 恵 (1998)：日本人の倫理的判断に影響す

る要因, インターナショナル・ナーシン

グ・レビュー, 21 (5), 31-34.

筒井真優美(1994)：小児看護と倫理 子どもの
人権と尊重を守るために，小児看護， 17 (4) , 394-400.

横尾京子 (1997) : ハイリスク新生児の看護と QOL：NICUに扔ける倫理的課題 意思決 定への親の参加, Neonatal Care, 10(4), 369-379.

横尾京子 (1996)：新生坚の治療をめぐる意思決 定に関する倫理的問題と看護婦の価値観, 臨床看護の進歩, 8, 91-97. 